\title{
Safety and nonclinical and clinical pharmacokinetics of PC945, a novel inhaled triazole antifungal agent
}

\author{
Lindsey Cass ${ }^{1}$, Alison Murray ${ }^{1}$, Amanda Davis ${ }^{1}$, Kathy Woodward ${ }^{1}$, Muna Albayaty ${ }^{2}$, \\ Kazuhiro Ito ${ }^{1}$, Pete Strong ${ }^{1}$, John Ayrton ${ }^{1}$, Charlie Brindley ${ }^{3}$, Jayne Prosser ${ }^{1}$, John \\ Murray $^{1}$, Eddie French ${ }^{1}$, Phillip Haywood ${ }^{1}$, Christopher Wallis $^{1}$, and Garth Rapeport ${ }^{1}$ \\ ${ }^{1}$ Pulmocide Ltd \\ ${ }^{2}$ PAREXEL Early Phase Clinical Unit \\ ${ }^{3}$ KinetAssist Limited
}

September 11, 2020

\begin{abstract}
Aims PC945 is a novel antifungal triazole for nebulised delivery to treat lung Aspergillus infections. Pharmacokinetic and safety profiles from nonclinical studies and clinical trials in healthy subjects and subjects with mild asthma were characterised. Methods Toxicokinetics were assessed following daily 2-hour inhalation for 14 days. Drug-drug interactions were evaluated using pooled human liver microsomes. Clinical safety and pharmacokinetics were assessed following (i) single inhaled doses (0.5-10 $\mathrm{mg}$ ), (ii) 7-day repeat doses (5 mg daily) in healthy subjects; (iii) a single dose (5 mg) in subjects with mild asthma. Results $\mathrm{C}_{\text {max }}$ occurred 4 hours (rats) or immediately (dogs) after a single dose. PC945 lung concentrations were substantially higher (>2000-fold) than those in plasma. PC945 only inhibited CYP3A4/5 substrate metabolism (IC $50: 1.33 \mu \mathrm{M}$ [testosterone] and $0.085 \mu \mathrm{M}$ [midazolam]). Geometric mean $\mathrm{C}_{\max }$ was $322 \mathrm{pg} / \mathrm{mL}$ (healthy subjects) and $335 \mathrm{pg} / \mathrm{mL}$ (subjects with mild asthma) 4-5 hours (median $t_{\max }$ ) after a single inhalation $(5 \mathrm{mg})$. Following repeat, once daily inhalation $(5 \mathrm{mg}), \mathrm{Day} 7 \mathrm{C} \max \mathrm{was} 951$ $\mathrm{pg} / \mathrm{mL}(0.0016 \mu \mathrm{M}) 45$ minutes after dosing. Increases in $\mathrm{C}_{\max }$ and $\mathrm{AUC}_{0-24 \mathrm{~h}}$ were approximately dose proportional (0.5-10 mg). PC945 administration was well tolerated in both healthy subjects and subjects with mild asthma. Treatment-emergent adverse events were mild/moderate and resolved before the study ended. No clinically significant lung function changes were observed. Conclusions PC945 pharmacokinetics translated from nonclinical species to humans showed slow absorption from lungs and low systemic exposure, thereby limiting the potential for adverse side effects and drug interactions commonly seen with systemically delivered azoles.
\end{abstract}

Safety and nonclinical and clinical pharmacokinetics of PC945, a novel inhaled triazole antifungal agent

Authors: Lindsey Cass $^{1}$, Alison Murray $^{1}$, Amanda Davis ${ }^{1}$, Kathy Woodward ${ }^{1}$, Muna Albayaty $^{2}$, Kazuhiro Ito ${ }^{1}$, Pete Strong ${ }^{1}$, John Ayrton ${ }^{1}$, Charlie Brindley ${ }^{3}$, Jayne Prosser ${ }^{1}$, John Murray ${ }^{1}$, Eddie French ${ }^{1}$, Phillip Haywood ${ }^{1}$, Christopher Wallis ${ }^{1}$ and Garth Rapeport ${ }^{1}$

\section{Affiliations:}

${ }^{1}$ Pulmocide Ltd, London, WC2A 1AP, UK

${ }^{2}$ Parexel Early Phase Clinical Unit Level 7, Northwick Park Hospital, Watford Road, Harrow, Middlesex, London, HA1 3UJ, UK

${ }^{3}$ KinetAssist Limited, Larchwood, Shieldhill Road, Quothquan, Lanarkshire, ML12 6NA, UK 
Corresponding author:Dr Lindsey Cass Pulmocide Ltd, London, WC2A 1AP, UK Phone: +44 7766 250133 Email: Lindsey@pulmocide.com

Principal Investigator statement: The authors confirm that the Principal Investigator for this paper is Muna Albayaty and that she had direct clinical responsibility for the subjects included in the study.

Running title: PC945 safety and pharmacokinetic profiles

Keywords: PC945, inhaled administration, safety, pharmacokinetics, drug-drug interaction, first-in-human, antifungal

\title{
WHAT IS ALREADY KNOWN ABOUT THIS SUBJECT
}

- The high plasma drug concentrations required to treat pulmonary fungal infections with current systemic therapies are commonly associated with side effects and drug-drug interactions.

- PC945, a novel triazole, inhibits planktonic growth and bronchial epithelial cell infection by Aspergillus species in vitro .

\section{WHAT THIS STUDY ADDS}

- Findings from clinical and nonclinical studies demonstrated that repeat daily doses of inhaled PC945 led to prolonged absorption from the lung and minimal systemic exposure.

- PC945 was well tolerated in healthy subjects and subjects with mild asthma.

- Inhaled PC945 should have a wider therapeutic index than systemic antifungal agents.

\section{ABSTRACT}

\begin{abstract}
Aims
PC945 is a novel antifungal triazole for nebulised delivery to treat lung Aspergillus infections. Pharmacokinetic and safety profiles from nonclinical studies and clinical trials in healthy subjects and subjects with mild asthma were characterised.
\end{abstract}

\section{Methods}

Toxicokinetics were assessed following daily 2-hour inhalation for 14 days. Drug-drug interactions were evaluated using pooled human liver microsomes. Clinical safety and pharmacokinetics were assessed following (i) single inhaled doses (0.5-10 mg), (ii) 7-day repeat doses (5 mg daily) in healthy subjects; (iii) a single dose $(5 \mathrm{mg})$ in subjects with mild asthma.

\section{Results}

$\mathrm{C}_{\max }$ occurred 4 hours (rats) or immediately (dogs) after a single dose. PC945 lung concentrations were substantially higher (>2000-fold) than those in plasma. PC945 only inhibited CYP3A4/5 substrate metabolism $\left(\mathrm{IC}_{50}: 1.33 \mu \mathrm{M}\right.$ [testosterone] and $0.085 \mu \mathrm{M}$ [midazolam]). Geometric mean $\mathrm{C}_{\max }$ was $322 \mathrm{pg} / \mathrm{mL}$ (healthy subjects) and $335 \mathrm{pg} / \mathrm{mL}$ (subjects with mild asthma) 4-5 hours (median $\mathrm{t}_{\max }$ ) after a single inhalation $(5 \mathrm{mg})$. Following repeat, once daily inhalation $(5 \mathrm{mg})$, Day $7 \mathrm{C}_{\max }$ was $951 \mathrm{pg} / \mathrm{mL}(0.0016 \mu \mathrm{M}) 45 \mathrm{minutes}$ after dosing. Increases in $\mathrm{C}_{\max }$ and $\mathrm{AUC}_{0-24 \mathrm{~h}}$ were approximately dose-proportional (0.5-10 mg). PC945 administration was well tolerated in both healthy subjects and subjects with mild asthma. Treatmentemergent adverse events were mild/moderate and resolved before the study ended. No clinically significant lung function changes were observed.

\section{Conclusions}


PC945 pharmacokinetics translated from nonclinical species to humans showed slow absorption from lungs and low systemic exposure, thereby limiting the potential for adverse side effects and drug interactions commonly seen with systemically delivered azoles.

\section{INTRODUCTION}

Incidence of fungal infections has increased substantially over the past two decades. ${ }^{1}$ Immunocompromised or immunosuppressed patients are particularly susceptible to such infections and invasive forms remain a leading cause of morbidity and mortality for these patients. ${ }^{2}$ Pulmonary aspergillosis, caused by Aspergillus , is particularly problematic. ${ }^{3}$ Aspergillus fumigatus is one of the primary causative agents of lung infections in humans. ${ }^{4}$ Chronic Aspergillusinfections can leave patients with permanent lung damage, requiring life-long management using oral azole treatment. ${ }^{5}$

Existing treatments for fungal infections are administered orally (azoles) or intravenously (azoles, amphotericin B or the echinocandins). ${ }^{6}$ Azole antifungals are potent inhibitors of cytochrome P450 (CYP450) enzymes, especially the CYP3A4 isoenzyme, which is responsible for the metabolism of a broad range of drugs. ${ }^{7}$ This inhibition presents a significant risk of interactions with other co-medicated drugs. To allow orally or intravenously administered antifungal agents to achieve high local concentrations sufficient for pathogen clearance, systemic exposure must be high, resulting in poor safety profiles. ${ }^{8,9}$

Nebulised delivery of antifungal agents results in higher local exposure in the epithelial lining fluid compared with intravenous administration. ${ }^{10} \mathrm{PC} 945$ is the first antifungal triazole specifically designed to treat pulmonary infection via inhaled administration. ${ }^{11}$ In common with other triazole agents, PC945 inhibits the enzyme lanosterol $14 \alpha$-demethylase (CYP51A1) in fungus, which prevents conversion of lanosterol to ergosterol. ${ }^{12,13}$ Reduction of ergosterol causes disruption to the structure and function of fungal membranes, hence inhibiting fungal growth and spread. PC945 inhibits in vitroplanktonic growth and bronchial epithelial cell infection by $A$. fumigatus.${ }^{13,14}$ In animal models, PC945 delivered a sustained and persistent antifungal effect in the lung when administered intranasally. ${ }^{15}$ In addition, PC945 was more effective than alternative antifungal agents because of a higher local exposure at the infected site, which was attributed to the intranasal administration delivering the compound directly to the lung. ${ }^{13,15}$

In this article, we report the pharmacokinetic profile of PC945 in nonclinical studies after single and repeat inhaled doses in rats and dogs. We also present the results from a Phase 1 study, which evaluated the safety, tolerability and pharmacokinetics of single (escalating) and repeat inhaled doses of PC945 in healthy subjects, as well as the safety and tolerability of a single dose of inhaled PC945 in subjects with mild asthma. (ClinicalTrials.gov Identifier: NCT02715570)

\section{METHODS}

\subsection{Drug}

For nonclinical studies, PC945 was synthesised by Sygnature Discovery Ltd (Nottingham, UK). PC945 powder was directly suspended in sodium phosphate-buffered saline containing wetting agents to $10 \mathrm{mg} / \mathrm{mL}$ and further diluted with physiological saline after sonication to obtain the desired dose concentration.

For the clinical study, PC945 was manufactured by Onyx Scientific Ltd (Sunderland, UK) and supplied as a powder at a single strength of $14 \mathrm{mg} /$ vial (Juniper Pharma, Nottingham, UK) for reconstitution using placebo solution. Placebo was supplied in a similar vial (Nova Laboratories, Leicester, UK). PC945 and placebo were administered by oral inhalation using a PARI LC SPRINT ${ }^{\circledR}$ nebuliser and PARI TurboBoy SX ${ }^{\circledR}$ compressor (PARI Medical Ltd., Surrey, UK). 


\subsection{Nonclinical toxicokinetic studies}

All animal studies were designed to meet the requirements of European Parliament and Council Directive 2001/83/EC and its amendment, Commission Directive 2003/63/EC. ${ }^{16,17}$

PC945 was administered to rats (Han Wistar) and dogs (Beagle) at nominal doses of approximately 2, 7 and $18 \mathrm{mg} / \mathrm{kg}$. Each dose was inhaled over a 2-hour period once daily for 14 days. Blood samples $(0.3 \mathrm{~mL}$ for rats and $0.5 \mathrm{~mL}$ for dogs) were collected at six timepoints ranging from 0 to 22 hours post-end of inhalation on Day 1 (single dose systemic exposure) and on Day 14 (repeat dose exposure). Lung samples were taken from rats on Day 15 to measure PC945 lung concentrations.

\subsection{In vitro drug-drug interactions}

PC945 and posaconazole (Sigma-Aldrich, UK) were added to the pooled human liver microsomal samples (Pharmaron Rushden, UK) at concentrations of $0,0.03,0.1,0.3,1,3$ and $5 \mu \mathrm{M}$. The mixtures were preincubated at $37^{\circ} \mathrm{C}$ for 0 or 30 minutes before the addition of selective CYP substrates. Microsomal reactions were terminated by adding $100 \mu \mathrm{L}$ of cold $\left(4^{\circ} \mathrm{C}\right)$ methanol containing appropriate internal standard. Aliquots $(150 \mu \mathrm{L})$ of each sample were centrifuged and the supernatant was used for substrate analysis by ultra-performance liquid chromatography with tandem mass spectrometry (UPLC-MS/MS) on the day of incubations.

Change in substrate concentration was measured to determine the extent of CYP-isoform inhibition. The 30-minute pre-incubations were performed to determine whether there was time-dependent inhibition of any CYP isoform (CYP1A2, 2B6, 2C8, 2C9, 2C19, 2D6 and 3A4/5). Untreated control contained only solvent, dimethyl sulfoxide (DMSO; [?]0.5\% [v/v]). Positive control contained a chemical inhibitor selective for each CYP enzyme in the presence of PC945 or posaconazole.

\subsection{In vitro plasma protein binding}

Plasma protein binding of PC945 was determined by ultrafiltration in pooled plasma samples from human, dog, rat and mouse. PC945 was tested at $0.1,1,5,25$ and $50 \mu \mathrm{M}$ in plasma for each species. PC945containing plasma samples were centrifuged at $45,000 \mathrm{rpm}$ for 20 hours at $37^{\circ} \mathrm{C}$. Supernatant was removed and diluted. The concentration of unbound PC945 was determined using LC-MS/MS, from which the extent of protein binding was calculated.

\subsection{Clinical trial}

\subsubsection{Trial design}

This PC945 first-in-human clinical trial (ClinicalTrials.gov Identifier: NCT02715570) was a two-part randomised, placebo-controlled study to assess the safety and tolerability of PC945 in both healthy subjects and subjects with mild asthma, conducted at Parexel Early Phase Clinical Unit (Harrow, UK). The study was considered single-blind as the appearance of active and placebo doses were different, however, it was conducted in a double-blind manner (employing separate dosing and assessment teams).

Part one consisted of a single dose escalation study (Cohort 1) and a repeat dose study (Cohort 2) of inhaled PC945 in healthy subjects. Part two comprised a single dose study of inhaled PC945 in subjects with mild asthma (Cohort 3). The protocol and informed consent form were developed according to the International Council for Harmonisation consolidated guideline for Good Clinical Practice and local regulations and were approved by an Independent Ethics Committee. All subjects signed a written informed consent form before enrolment.

In Cohort 1, 11 healthy subjects (three males and eight females; mean age: 48.5 years, mean weight: $65.32 \mathrm{~kg}$, mean body mass index [BMI]: $23.62 \mathrm{~kg} / \mathrm{m}^{2}$ ), attended the single ascending dose study. Eight 
healthy subjects started the study in which two subjects were randomised to each of the four ascending dose treatment sequences (Table 1); two subjects withdrew due to adverse events unrelated to study medication and both were replaced. One of the replacement subjects subsequently withdrew from the study for personal reasons and was replaced by another subject (Figure 1). Overall, six subjects each received three of four doses of PC945 (0.5, 2, 5, and $10 \mathrm{mg})$ and one dose of placebo.

Nine healthy subjects (four males and five females; mean age: 33.2 years, mean weight: $66.5 \mathrm{~kg}$, mean BMI: $\left.23.53 \mathrm{~kg} / \mathrm{m}^{2}\right)$ whose forced expiratory volume over 1 second $\left(\mathrm{FEV}_{1}\right)$ and forced vital capacity (FVC) were [?] $80 \%$ of predicted values with an $\mathrm{FEV}_{1} / \mathrm{FVC}$ ratio $>0.7$, received once daily doses of PC945 $5 \mathrm{mg}$ or placebo for 7 days (Cohort 2, PC945:placebo=2:1).

In Cohort 3, nine subjects with mild asthma (six males and three females; mean age: 37.7 years, mean weight: $82.70 \mathrm{~kg}$, mean BMI: $26.48 \mathrm{~kg} / \mathrm{m}^{2}$ ) received a single dose of PC945 $5 \mathrm{mg}$ or placebo (PC945:placebo=2:1). Subjects with mild asthma needed to demonstrate a methacholine $\mathrm{PC}_{20}$ (concentration of inhaled agonist leading to a fall in $\mathrm{FEV}_{1}$ of [?] $20 \%$ of personal best) [?] $8 \mathrm{mg} / \mathrm{mL}$ at screening and an $\mathrm{FEV}_{1}>60 \%$ of predicted normal value at least 6 hours after the last use of a short acting $\beta$-agonist.

Subjects returned to the study unit for a final follow-up visit 10 days after the last administration of study medication.

\subsubsection{Sample collection and handling}

Serial blood samples were collected to determine plasma PC945 concentrations. For the single dose study in healthy subjects and in subjects with mild asthma, blood samples were collected pre-dose and at 0.25 , $0.5,1,2,4,6,8,24,30$ and 48 hours post-end of inhalation and at the follow-up visit. For the repeat dose study, blood samples were collected (i) pre-dose and at $0.25,0.5,1,2,4,6,8,10,12$ and 24 hours post-end of inhalation on Days 1 and 7, and 30 and 48 hours on Day 7; (ii) pre-dose on Days 5 and 6; (iii) at the follow-up visit.

\subsubsection{Safety assessment}

Safety was evaluated based on assessments of adverse events, physical examination, vital signs, 12-lead electrocardiogram, spirometry and clinical laboratory tests. The verbatim terms used to identify adverse events were coded using the Medical Dictionary for Regulatory Activities (version 20.1). All adverse events were mapped to system organ class and preferred term.

Spirometry parameters $\left(\mathrm{FEV}_{1}\right.$ and $\left.\mathrm{FVC}\right)$ were measured in all subjects to evaluate the local tolerability and potential for bronchospasm of PC945 in accordance with American Thoracic Society/European Respiratory Society guidelines. Predicted values were calculated using National Health and Nutrition Examination Survey reference equations. ${ }^{18,19}$

\subsection{Plasma sample analysis}

PC945 concentrations were determined by a validated, specific and sensitive LC-MS/MS method under the supervision of LGC Ltd (Fordham, UK) after the drug was extracted from plasma samples. Lower limit of quantification of the assay was $10 \mathrm{pg} / \mathrm{mL}$ for clinical samples and $100 \mathrm{pg} / \mathrm{mL}$ for rat and dog plasma samples.

\subsection{Pharmacokinetic analysis}

Plasma pharmacokinetic parameters of PC945 were estimated using a fully validated version of Phoenix WinNonlin ${ }^{\circledR}$ (version 8.0; Certara, NJ, USA). The estimated pharmacokinetic parameters included the maximum observed concentration $\left(\mathrm{C}_{\max }\right)$, time to $\mathrm{C}_{\max }\left(\mathrm{t}_{\max }\right)$, the area under the plasma concentration 
versus time curve (AUC) from 0 to 24 hours post-dose $\left(\mathrm{AUC}_{0-24 \mathrm{~h}}\right)$, the apparent terminal half-life $\left(\mathrm{t}_{1 / 2}\right)$ and the accumulation ratio $\left(\mathrm{R}_{\mathrm{o}}\right)$.

Attainment of steady state was assessed by visual inspection of the pre-dose plots during the 7-day treatment period in human subjects.

\subsection{Analysis of lung samples}

Portions of rat lung tissue were homogenised in methanol:water (50:50; $15 \mathrm{~mL}$ for $1 \mathrm{~g}$ tissue). PC945 concentrations in tissue homogenates were analysed using LC-MS/MS. A control rat lung sample (B\&K Universal Ltd, Hull, UK) was used as standards and quality control.

\section{RESULTS}

\subsection{Nonclinical toxicokinetic data}

\subsubsection{Single dose toxicokinetic studies in rats and dogs}

Following inhalation of PC945, the increase in systemic exposure was less than proportional at doses of 2.0, 7.4 and $16.6 \mathrm{mg} / \mathrm{kg}$. Systemic exposure to PC945 was consistently higher in female than in male rats (Table 2). $\mathrm{C}_{\max }$ occurred 6 hours after the start of dosing and PC945 was detectable throughout the 24-hour sampling period after dosing.

The magnitude of exposure obtained in dogs was lower than that in rats at similar dose/kg levels. There was a slightly less than dose-proportional increase in systemic exposure at inhaled PC945 doses of 1.7, 5.3 and $18.1 \mathrm{mg} / \mathrm{kg}$ in dogs, and no notable differences in mean values of $\mathrm{C}_{\max }$ and $\mathrm{AUC}_{0-24 \mathrm{~h}}$ between male and female dogs (Table 3). $\mathrm{C}_{\max }$ was reached in the samples taken immediately after the 2-hour dosing period; exposure extended for the full 24-hour sampling period at all doses.

\subsubsection{Repeat dose toxicokinetic studies in rats and dogs}

In both test species, daily systemic exposure was higher on Day 14 than Day 1 following inhaled dosing with PC945 suspension. In rats the $\mathrm{R}_{\mathrm{o}}$ values for $\mathrm{C}_{\max }$ were similar to those for $\mathrm{AUC}_{0-24 \mathrm{~h}}$ (ranging from 1.8to 2.8-fold) and showed no sex dependence (Table 4). There was a trend towards greater accumulation in the highest dose group tested. In dogs, the $\mathrm{R}_{\mathrm{o}}$ values for $\mathrm{C}_{\max }$ were lower than those for $\mathrm{AUC}_{0-24 \mathrm{~h}}$ (ranging from 1.3- to 2.3-fold) on Day 14 (Table 5).

Determination of lung exposure in rats on Day 15 confirmed that the concentration of PC945 in lung samples increased with the daily dose administered. PC945 concentrations in the lung were substantially higher ( $>2000$-fold) than those detected in plasma at all dose levels. There was no clear sex effect in the magnitude of PC945 concentrations in the Day-14 lung tissue samples; however, the ratio of lung to plasma PC945 concentration was consistently lower in female rats, reflecting the sex effect of apparent clearance for PC945 in rats (Table 6).

\subsection{In vitro drug-drug interaction}

The only cytochrome P450 inhibitory interaction observed for PC945 was that on CYP3A4/5 substrates. Without pre-incubation, PC945 showed $\mathrm{IC}_{50}$ values of $1.33 \mu \mathrm{M}$ and $0.085 \mu \mathrm{M}$ for testosterone and midazolam, respectively. The control CYP3A4/5 inhibitor posaconazole showed differences to PC945 in both inhibitory potency and specificity, with $\mathrm{IC}_{50}$ values of $0.081 \mu \mathrm{M}$ and $0.32 \mu \mathrm{M}$ for testosterone and midazolam, respectively. 
Following a 30-minute pre-incubation, PC945 demonstrated a 5 -fold shift in potency for CYP3A4/5 (IC 50 values: $0.247 \mu \mathrm{M}$ [i.e., $168 \mathrm{ng} / \mathrm{mL}$; testosterone] and $0.017 \mu \mathrm{M}$ [i.e., $11.6 \mathrm{ng} / \mathrm{mL}$; midazolam]). PC945 had no time-dependent effect on other CYP isoforms.

\subsection{In vitro plasma protein binding}

PC945 was highly bound to plasma proteins in all species and the extent of binding was independent of the concentration over a range of $0.1 \mu \mathrm{M}$ to $50 \mu \mathrm{M}$. Mean extent of protein binding was between $96 \%$ and $98 \%$ in human, mouse and rat plasma and $91 \%$ in dog plasma (Table 7 ).

\subsection{Clinical study data}

\subsubsection{Safety and tolerability}

PC945 was well tolerated following single doses up to $10 \mathrm{mg}$ and repeat doses of $5 \mathrm{mg}$ daily for 7 days in healthy subjects, and at a single dose of $5 \mathrm{mg}$ in subjects with mild asthma. Escalation of single doses of PC945 from 0.5 to $10 \mathrm{mg}$ was not associated with an increase in treatment-emergent adverse events. All treatment-emergent adverse events were either mild or moderate in intensity and resolved before the end of the study. There were no deaths or serious adverse events in the study. Drug-related treatment-emergent adverse events are summarised in Table 8. In total, seven adverse events required intervention; only one of these was considered drug-related (headache, following a single $10 \mathrm{mg}$ dose of PC945).

No clinically significant changes in lung function were observed in healthy subjects. Importantly, no evidence of acute bronchospasm or significant change in lung function (defined as $>15 \%$ change from baseline) was observed in any subject with mild asthma who received PC945. One subject had a transient reduction in $\mathrm{FEV}_{1}$ values $>15 \%$ compared with baseline 10 minutes after receiving a dose of placebo.

There were no notable differences in mean laboratory values, vital signs, electrocardiogram results or spirometry values (Figure 2) between the placebo and PC945 groups. No clinically significant abnormal laboratory results considered to be related to study drug were reported in any cohort.

\subsubsection{Pharmacokinetics}

\subsubsection{Single dose in healthy subjects (Cohort 1)}

Following single inhaled administration of PC945 at 0.5, 2, 5 and $10 \mathrm{mg}$ in healthy subjects, geometric mean $\mathrm{C}_{\max }$ values of $54.7,128,322$ and $619 \mathrm{pg} / \mathrm{mL}$ in plasma were achieved at 1, 4, 5 and 2 hours (median $t_{\max }$ ) post-end of inhalation, respectively (Table 9 and Figure 3 ). Geometric mean $\mathrm{t}_{\frac{1}{2}}$ ranged from 27.9 to 110 hours over the entire dose range. However, the period over which estimated $t_{\frac{1}{2}}$ was calculated was less than 2 -fold the $t_{\frac{1}{2}}$ itself and the area extrapolated was greater than $20 \%$ in most cases; estimated $t_{\frac{1}{2}}$ was therefore considered to be unreliable at each dose level. Between-subject variability in the extent of systemic exposure to PC945 at $0.5,2,5$ and $10 \mathrm{mg}$ was moderate to high, as revealed by geometric coefficient of variations (CVs) for $\mathrm{C}_{\max }$ and $\mathrm{AUC}_{0-24 \mathrm{~h}}$ ranging from $39.1 \%$ to $107 \%$. Systemic exposure to $\mathrm{PC} 945$ in female subjects was not appreciably different to that in male subjects.

\subsubsection{Single dose in subjects with mild asthma (Cohort 3)}

Following single inhaled administration of PC945 at $5 \mathrm{mg}$, a geometric mean $\mathrm{C}_{\max }$ of $335 \mathrm{pg} / \mathrm{mL}$ in plasma was achieved 4 hours (median $t_{\max }$ ) post-dose (Figure 4). Between-subject variability in the extent of systemic exposure to PC945 was moderate to high, with geometric $\mathrm{CVs}$ for $\mathrm{C}_{\max }$ and $\mathrm{AUC}_{0-24 \mathrm{~h}}$ of $68.7 \%$ and $49.7 \%$, respectively. Systemic exposure to PC945 $\left(\mathrm{C}_{\max }\right.$ and $\left.\mathrm{AUC}_{0-24 \mathrm{~h}}\right)$ in subjects with mild asthma $(335 \mathrm{pg} / \mathrm{mL}$ and $4950 \mathrm{pg}^{*} \mathrm{~h} / \mathrm{mL}$, respectively) was not meaningfully different from that in healthy subjects at $5 \mathrm{mg}$ (322 $\mathrm{pg} / \mathrm{mL}$ and $5440 \mathrm{pg}^{*} \mathrm{~h} / \mathrm{mL}$, respectively).

3.4.2.3. Repeat dose in healthy subjects (Cohort 2) 
Following a single inhaled administration of PC945 $5 \mathrm{mg}$ on Day 1, a geometric mean $\mathrm{C}_{\max }$ of $462 \mathrm{pg} / \mathrm{mL}$ in plasma was achieved 2 hours (median $t_{\max }$ ) post-end of inhalation (Table 10 and Figure 3 ).

Following repeat daily inhaled administration of PC945 $5 \mathrm{mg}$, a geometric mean $\mathrm{C}_{\max }$ of $951 \mathrm{pg} / \mathrm{mL}$ was achieved at 45 minutes post-end of inhalation on Day 7. Systemic exposure to PC945 $\left(\mathrm{AUC}_{0-24 \mathrm{~h}}\right)$ increased 2.6-fold following 7-day dosing; visual inspection of pre-dose concentrations indicated that steady state had not been reached by Day 7 (Figure 5). Between-subject variability in the extent of systemic drug exposure was moderate with geometric $\mathrm{CVs}$ for $\mathrm{C}_{\max }$ and $\mathrm{AUC}_{0-24 \mathrm{~h}}$ ranging from $58.7 \%$ to $60.9 \%$.

\subsection{Dose proportionality}

Systemic exposure to PC945 $\left(\mathrm{C}_{\max }\right.$ and $\left.\mathrm{AUC}_{0-24 \mathrm{~h}}\right)$ increased with escalating doses from 0.5 to $10 \mathrm{mg}$ in an approximately dose-proportional manner. For a doubling in dose, $\mathrm{C}_{\max }$ and $\mathrm{AUC}_{0-24 \mathrm{~h}}$ values increased 1.77-fold and 1.88 -fold,; the $90 \%$ confidence interval was within the prescribed limits of 1.6 to 2.5 for $\mathrm{AUC}_{0-24 \mathrm{~h}}$ (values $1.64,2.15$ ) indicating dose proportionality, though just outside the lower limit for $\mathrm{C}_{\max }$ (values $1.54,2.02$ )

\section{DISCUSSION}

PC945 is a novel antifungal triazole, designed specifically for inhaled administration with physico-chemical properties for sustained lung retention and persistent antifungal activity. ${ }^{13}$ Drug delivery directly to the lung to treat pulmonary disease is well established. ${ }^{20,21}$ This dosing route maximises local efficacy in the lungs whilst minimising the potential for adverse systemic effects or drug interactions. Administration of a drug solution into the lung leads to rapid absorption into the systemic circulation; consequently strategies for developing effective inhaled medicines have focused on lipophilic compounds that have low aqueous solubility and slow dissolution rates in aqueous media. ${ }^{22}$ Such compounds are typically delivered to the lungs in a micronized, crystalline form as either an aqueous suspension, a pressurised metered dose inhaler or a dry powder blended with a carrier such as lactose. The slow dissolution of inhaled drug particles enhances local action by prolonging lung retention, whilst simultaneously delaying the rate of delivery to the systemic circulation. This strategy was adopted in the development of PC945. ${ }^{13}$

Following single inhaled doses in rats (Day 1 data), PC945 showed a slow and sustained period of absorption into the systemic circulation such that $\mathrm{C}_{\max }$ occurred 6 hours after the start of dosing. Similarly, in dogs, there was a slow rate of PC945 absorption from the lung followed by sustained plasma levels that extended beyond 24 hours after the initial dose. Systemic exposure was approximately dose-proportional in both test species. The slow rate of PC945 absorption indicated that accumulation of PC945 would occur with repeat daily dosing in rats and dogs. Repeat dose studies confirmed that dose absorption from the lungs was a rate-limiting process in the pharmacokinetic profile of inhaled PC945.

The pharmacokinetic profile of PC945 in humans showed similar drug behaviour to that observed in the nonclinical species investigated. Systemic exposure to PC945 in humans $\left(\mathrm{C}_{\max }\right.$ and $\left.\mathrm{AUC}_{0-24 \mathrm{~h}}\right)$ increased with escalating doses of 0.5 to $10 \mathrm{mg}$ in a dose-proportional manner. Following 7-day, once daily dosing with $5 \mathrm{mg}$ PC945, $\mathrm{AUC}_{0-24 \mathrm{~h}}$ increased 2.6-fold. Visual inspection of pre-dose plasma concentrations indicated that steady state had not been reached by Day 7 , and was predicted to be attained approximately 5 weeks after once daily dosing. The prolonged plasma $t_{1 / 2}$ (from 37.3 hours on Day 1 to 132 hours on Day 7 ) was consistent with slow absorption from the lung, demonstrating that a typical lung-dominant process was controlling systemic kinetic behaviour. A rapid $t_{\max }$ of 45 minutes on Day 7 was observed in healthy subjects who received $5 \mathrm{mg}$ PC945 once daily, suggesting rapid exposure to the respiratory epithelium.

In rat lung samples on Day 15 after 14-day inhaled dosing, mean concentrations of PC945 were approximately proportional to daily doses and $>2000$-fold (range 2340 to 5020) higher than the concentrations in plasma. The pharmacokinetic data obtained in rats and dogs indicate that the rates of dissolution and subsequent absorption of PC945 from the lungs are the principal factors determining systemic exposure to PC945 
following inhaled dosing. Based on the mean lung:plasma ratio observed in male rats ( $\sim 4,300$ fold) lung concentrations of PC945 in humans following a $5 \mathrm{mg}$ single dose were estimated to be in the region of the $90 \%$ of the minimal inhibitory concentration $\left(\mathrm{MIC}_{90}\right)$ for clinical strains of A. fumigatus $(1 \mu \mathrm{g} / \mathrm{mL}) .{ }^{13}$

One potential factor affecting distribution and clearance of PC945 in the lungs is uptake into macrophages in the alveolar space and/or epithelial cells. Several studies in humans investigating the intra-pulmonary pharmacokinetics of azole antifungal agents, such as itraconazole, voriconazole and posaconazole, have been reported..$^{23-26}$ For itraconazole and posaconazole, preferential distribution into alveolar cells could be a favourable factor for successful treatment and prevention of respiratory fungal disease. For example, 14-day oral administration of posaconazole (400 mg twice daily) resulted in steady state in which mean concentrations were over 30 -fold greater in pulmonary alveolar cells than in lung epithelial lining fluid and plasma, with an alveolar cell:plasma ratio of 27 to 44 after the last dose. ${ }^{25}$ Similar pulmonary pharmacokinetic data have been reported with oral posaconazole treatment in lung transplant patients, suggesting that uptake into alveolar cells is a reproducible distribution characteristic of the compound in clinical studies. ${ }^{26}$ Preferential uptake of antifungal agents into alveolar cells (which are principally macrophages) could be clinically relevant, as macrophages are a host defence mechanism against alveolar infection by Aspergillus and scavenge to remove particulate matter. ${ }^{7,27}$

It is well known that all antifungal azoles are potent inhibitors of cytochrome P450 (CYP450) enzymes, leading to a significant risk of interactions with other co-medicated drugs. ${ }^{7,28}$ All of these agents potently inhibit human CYP3A4 isoforms and the inhibitory activity is extended to human CYP2C9 and CYP2C19 in the cases of fluconazole and voriconazole. ${ }^{7}$ It is also reported that posaconazole has the potential to inhibit CYP450-mediated steroid hormone synthesis causing hypertrophy or hyperplasia of the adrenal glands. ${ }^{29}$ These CYP inhibitory actions are well established as a mechanism of pharmacokinetics-based drug-drug interactions in the clinic. ${ }^{7}$ PC945 is a potent inhibitor of human CYP3A4/5. However, oral inhalation of PC945 resulted in low systemic exposure as demonstrated by a mean plasma $\mathrm{C}_{\max }$ of $951 \mathrm{pg} / \mathrm{mL}$ [equivalent to $0.0016 \mu \mathrm{M}$ ] following 7-day, once daily, $5 \mathrm{mg}$ doses, an order of magnitude lower than the inhibitory $\mathrm{IC}_{50}$ value $(0.017 \mu \mathrm{M}$; determined as the time-dependent value for in vitro inhibition of midazolam in pooled human liver microsomes). Moreover, the $\mathrm{C}_{\max }$ determined for PC945 $[0.0016 \mu \mathrm{M}]$ is much lower than that of either itraconazole $(1.52 \mu \mathrm{M}$ after 15-day, $200 \mathrm{mg}$ daily oral dosing) or posaconazole $(0.83 \mu \mathrm{M}$ after $200 \mathrm{mg}$ three times daily oral dosing). ${ }^{30,31}$ The low $\mathrm{C}_{\max } / \mathrm{IC}_{50}$ ratio of 0.1 for PC945 indicates that a systemic based, CYP3A4/5 mediated, hepatic drug-drug interaction is unlikely.

In the first-in-human study, reported herein, PC945 was well tolerated in healthy subjects at either single doses up to $10 \mathrm{mg}$ or at repeat doses of $5 \mathrm{mg}$ once daily for 7 days in addition to subjects with mild asthma at a single dose of $5 \mathrm{mg}$. No evidence of irritancy was observed in subjects with mild asthma.

In summary, PC945 was well tolerated at all doses tested and no safety signals were identified. The pharmacokinetic profile translated well from nonclinical species to results derived from the clinic. Key findings of the study reveal that PC945 undergoes slow absorption from the lung and exhibits low systemic exposure thus limiting the potential for an adverse side effect profile and drug interactions commonly seen with oral azoles. In addition, systemic exposure to PC945 in subjects with mild asthma showed no appreciable difference in its profile to that observed in healthy subjects at the same dose level, suggesting no dose adjustment would be anticipated in subsequent studies in patients. We demonstrated that $5 \mathrm{mg}$ is a suitable dose and the data, together with a case report describing the treatment of fungal tracheobronchitis post lung transplantation, support the further development of PC945 in studies of patients with pulmonary aspergillosis. ${ }^{32}$

\section{ACKNOWLEDGEMENTS}

Dr Yue Wu from Niche Science and Technology (Richmond-Upon-Thames, London, UK) provided writing and editorial support during the development of this manuscript. We thank LGC (Fordham, UK) for the PC945 assay development and the bioanalytical work to support the nonclinical and clinical studies, and 
Covance (formally Envigo; Huntingdon, UK) for conducting the animal toxicology studies from which the toxicokinetic data were reported. We would also thank the subjects who participated in the first-in-human study PC_ASP_001 and to the staff at Parexel Early Phase Clinical Unit (Harrow, UK) for conducting the study.

\section{CONFLICT OF INTERESTS}

All authors have completed the Unified Competing Interest form at http://www.icmje.org/coi_disclosure.pdf (available on request from the corresponding author). Pulmocide Ltd. provided funding for this clinical trial. LC, AM and AD are employees of Pulmocide Ltd and own stock options of Pulmocide Ltd. KI and PS are (co)founders and employees of Pulmocide Ltd, and own stock options of Pulmocide Ltd. JM and GR are (co)founders and consultants of Pulmocide Ltd. and own stocks of Pulmocide Ltd. KW, JA, JP, EF, PH and CW (are part-time consultants to Pulmocide Ltd)

\section{DATA AVAILABILITY STATEMENT}

The data that support the findings of this study are available from the corresponding author upon reasonable request. REFERENCES

1. Orlowski HLP, McWilliams S, Mellnick VM, Bhalla S, Lubner MG, Pickhardt PJ, et al . Imaging Spectrum of Invasive Fungal and Fungal-like Infections. Radiographics. 2017;37(4):1119-34.

2. Perlin DS, Rautemaa-Richardson R, Alastruey-Izquierdo A. The global problem of antifungal resistance: prevalence, mechanisms, and management. Lancet Infect Dis. 2017;17(12):e383-92.

3. Kosmidis C, Denning DW. The clinical spectrum of pulmonary aspergillosis. Thorax. 2015;70(3):2707 .

4. Dagenais TR, Keller NP. Pathogenesis of Aspergillus fumigatus in invasive aspergillosis. Clin. Microbiol. Rev. 2009;22(3):447-65.

5. Limper AH, Knox KS, Sarosi GA, Ampel NM, Bennett JE, Catanzaro A, et al . An Official American Thoracic Society Statement: Treatment of Fungal Infections in Adult Pulmonary and Critical Care Patients. Am. J. Respir. Crit. Care Med. 2011;183(1):96-128.

6. Alevizakos M, Farmakiotis D, Mylonakis E. Updated practice guidelines for the diagnosis and management of aspergillosis: challenges and opportunities. J Thorac Dis. 2016;8(12):e1767-70.

7. Brüggemann RJ, Alffenaar JW, Blijlevens NM, Billaud EM, Kosterink JG, Verweij PE, et al . Clinical relevance of the pharmacokinetic interactions of azole antifungal drugs with other coadministered agents. Clin Infect Dis. 2009;48(10):1441-58.

8. Thompson GR III, Lewis JS II. Pharmacology and clinical use of voriconazole. Expert Opin Drug Metab Toxicol. 2010;6(1):83-94.

9. Xiong WH, Brown RL, Reed B, Burke NS, Duvoisin RM, Morgans CW. Voriconazole, an antifungal triazol that causes visual side effects, is an inhibitor of TRPM1 and TRPM3 channels. Invest Ophthalmol Vis Sci. 2015;56(2):1367-73.

10. Rodvold KA, George JM, Yoo L. Penetration of anti-infective agents into pulmonary epithelial lining fluid: focus on antibacterial agents. Clin Pharmacokinet. 2011;50(10):637-64.

11. Sunose M, Colley TC, Ito K, Rapeport G, Strong P. Antimycotic Compound. WO/2016/087878 A1. 09.06.2016.

12. Como JA, Dismukes WE. Oral Azole Drugs as Systemic Antifungal Therapy. N Engl J Med. 1994;330(4):263-72.

13. Colley T, Alanio A, Kelly SL, Sehra G, Kizawa Y, Warrilow AGS, et al . In vitro and in vivo antifungal profile of a novel and long-acting inhaled azole, PC945, on Aspergillus fumigatus Infection. Antimicrob Agents Chemother. 2017;61(5):e02280-16. 
14. Colley T, Sehra G, Daly L, Kimura G, Nakaoki T, Nishimoto Y, et al . Antifungal synergy of a topical triazole, PC945, with a systemic triazole against respiratory Aspergillus fumigatus infection. Sci Rep. 2019;9(1):9482.

15. Kimura G, Nakaoki T, Colley T, Rapeport G, Strong P, Ito K, et al . In vivo biomarker analysis of the effects of intranasally dosed PC945, a novel antifungal triazole, on aspergillus fumigatus infection in immunocompromised mice. Antimicrob Agents Chemother. 2017;61(9):e00124-17.

16. European Parliament and Council Directive 2001/83/EC of 6 November 2001 on the Community code relating to medicinal products for human use. Official Journal of the European Union L 311/67-128, 28 November 2001.

17. European Commission (2003). Commission Directive 2003/63/EC of 25 June 2003 amending Directive 2001/83/EC of the European Parliament and of the Council on the Community code relating to medicinal products for human use. Official Journal of the European Union L 159/46-94, 27 June 2003.

18. Miller MR, Hankinson J, Brusasco V, Burgos F, Casaburi R, Coates A, et al . Standardisation of spirometry. Eur Respir J. 2005;26(2):319-338.

19. Hankinson JL, Odencrantz JR, Fedan KB. Spirometric reference values from a sample of the general U.S. population. Am J Respir Crit Care Med. 1999;159(1):179-187.

20. Borghardt JM, Kloft C, Sharma A. Inhaled Therapy in Respiratory Disease: The Complex Interplay of Pulmonary Kinetic Processes. Can Respir J. 2018;2018:2732017.

21. Hodson ME, Gallagher CG, Govan JR. A randomised clinical trial of nebulised tobramycin or colistin in cystic fibrosis. Eur Respir J. 2002;20(3):658-664.

22. Strong P, Ito K, Murray J, Rapeport G. Current approaches to the discovery of novel inhaled medicines. Drug Discov Today. 2018;23(10):1705-17.

23. Conte JE Jr, Golden JA, Kipps J, McIver M, Zurlinden E. Intrapulmonary pharmacokinetics and pharmacodynamics of itraconazole and 14-hydroxyitraconazole at steady state. Antimicrob. Agents Chemother. 2004;48(10):3823-7.

24. Capitano B, Potoski A, Husain S, Zhang S, Paterson DL, Studer SM, et al . 2006. Intrapulmonary penetration of voriconazole in patients receiving an oral prophylactic regimen. Antimicrob. Agents Chemother. 50:1878-1880.

25. Conte JE Jr, Golden JA, Krishna G, McIver M, Little E, Zurlinden E. Intrapulmonary pharmacokinetics and pharmacodynamics of posaconazole at steady state in healthy subjects. Antimicrob. Agents Chemother. 2009;53(2):703-7.

26. Conte JE Jr, DeVoe C, Little E, Golden JA. Steady-state intrapulmonary pharmacokinetics and pharmacodynamics of posaconazole in lung transplant recipients. Antimicrob. Agents Chemother. 2010;54(9): 3609-13.

27. Segal BH. Role of macrophages in host defence against aspergillosis and strategies for immune augmentation. Oncologist. 2007;12 Suppl 2:7-13.

28. Isoherranen N, Kunze KL, Allen KE, Nelson WL, Thummel KE. Role of itraconazole metabolites in CYP3A4 inhibition. Drug Metab Dispos. 2004;32(10):1121-31.

29. Barton K, Davis TK, Marshall B, Elward A, White NH. Posaconazole-induced hypertension and hypokalemia due to inhibition of the 11ß-hydroxylase enzyme. Clin Kidney J. 2018;11(5):691-3.

30. Hardin TC, Graybill JR, Fetchick R, Woestenborghs R, Rinaldi MG, Kuhn JG. Pharmacokinetics of itraconazole following oral administration to normal volunteers. Antimicrob Agents Chemother. 1988;32(9):1310-13.

31. Noxafil (posaconazole) Label: Food and Drug AdministrationReference ID : 3847805 - Food and Drug Administration. accessdata.fda.gov.

32. Pagani N, Murray A, Strong P, Ito K, Rapeport G, Cass L, et al.PC945, a novel inhaled azole for treatment of fungal tracheobronchitis post-lung transplantation: a case report. F1000 research 2019, 8:645 (poster). Available at https://doi.org/10.7490/f1000research.1116740.1 


\section{TABLES}

Table 1 Treatment sequences for the single ascending dose study (Cohort 1)

\section{Week $1^{\text {a,b }}$}

PC945 $0.5 \mathrm{mg}$

PC945 $0.5 \mathrm{mg}$

PC945 $0.5 \mathrm{mg}$

Placebo

a Sentinel dosing: two subjects (PC945:placebo=1:1) were dosed on Day 1; the remaining six subjects were dosed on Day 2

Table 2 Mean systemic exposure ${ }^{\mathrm{a}}$ to PC945 in male and female rats following single inhaled doses

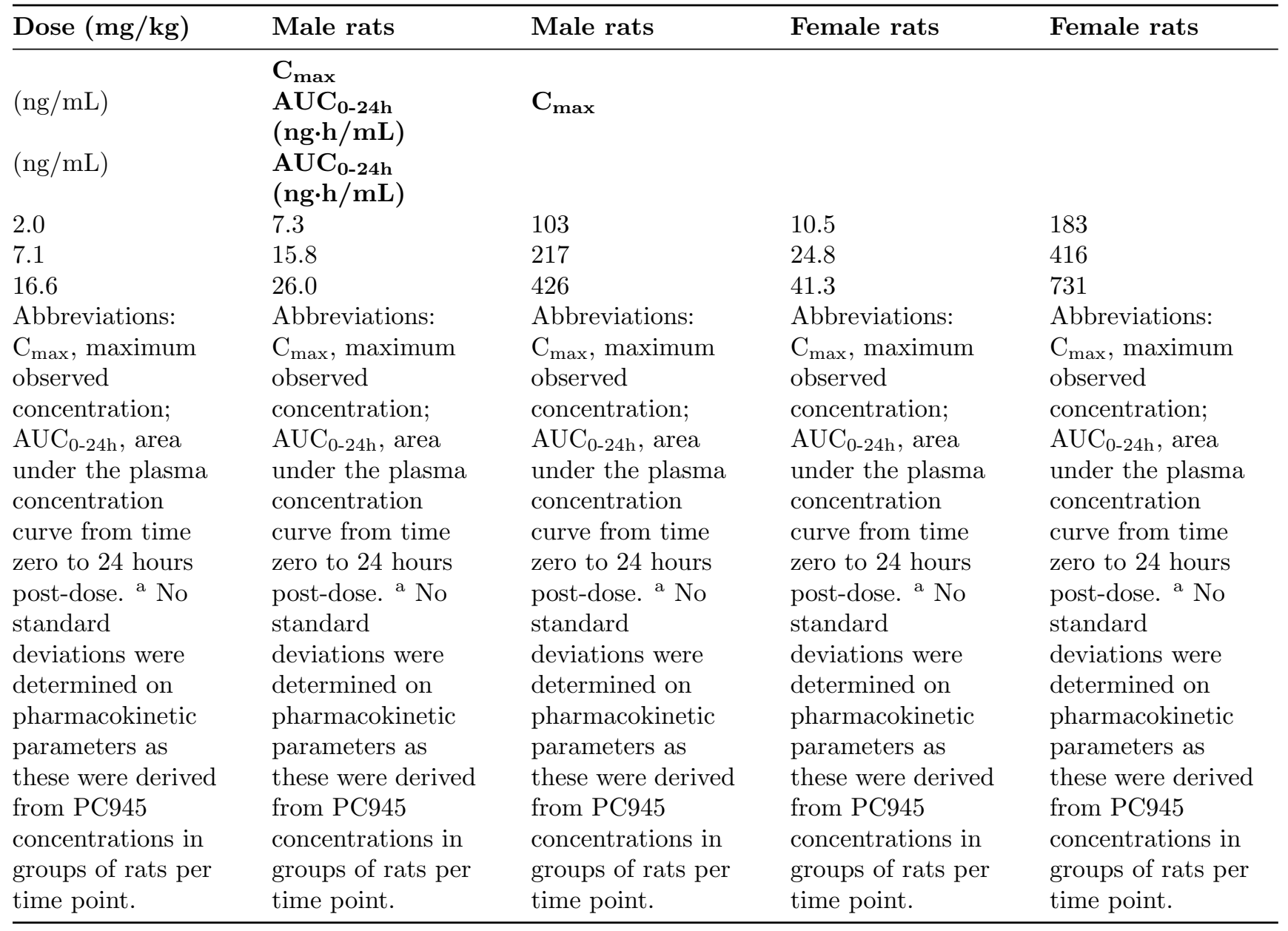

Table 3 Mean (standard deviation) systemic exposure to PC945 in male and female dogs following a single inhaled dose 


\begin{tabular}{|c|c|c|c|c|}
\hline Dose $(\mathrm{mg} / \mathrm{kg})$ & Male dogs & Male dogs & Female dogs & Female dogs \\
\hline & $\mathrm{C}_{\max }(\mathrm{ng} / \mathrm{mL})$ & $\begin{array}{l}\mathrm{AUC}_{0-24 \mathrm{~h}} \\
(\mathrm{ng} \cdot \mathrm{h} / \mathrm{mL})\end{array}$ & $\mathrm{C}_{\max }(\mathrm{ng} / \mathrm{mL})$ & $\begin{array}{l}\mathrm{AUC}_{0-24 h} \\
(\mathrm{ng} \cdot \mathrm{h} / \mathrm{mL})\end{array}$ \\
\hline 1.7 & $2.2 \pm 0.3$ & $17.2 \pm 3.5$ & $1.5 \pm 0.5$ & $12.2 \pm 2.9$ \\
\hline 5.3 & $4.6 \pm 0.4$ & $38.5 \pm 1.8$ & $4.3 \pm 0.7$ & $39.0 \pm 2.7$ \\
\hline 18.1 & $9.7 \pm 2.4$ & $88.5 \pm 25.8$ & $10.2 \pm 1.3$ & $90.6 \pm 6.7$ \\
\hline Abbreviations: & Abbreviations: & Abbreviations: & Abbreviations: & Abbreviations: \\
\hline $\begin{array}{l}\mathrm{C}_{\max }, \text { maximum } \\
\text { observed }\end{array}$ & $\begin{array}{l}\mathrm{C}_{\max }, \text { maximum } \\
\text { observed }\end{array}$ & $\begin{array}{l}\mathrm{C}_{\max }, \text { maximum } \\
\text { observed }\end{array}$ & $\begin{array}{l}\mathrm{C}_{\max }, \text { maximum } \\
\text { observed }\end{array}$ & $\begin{array}{l}\mathrm{C}_{\max }, \text { maximum } \\
\text { observed }\end{array}$ \\
\hline concentration; & concentration; & concentration; & concentration; & concentration; \\
\hline $\mathrm{AUC}_{0-24 \mathrm{~h}}$, area & $\mathrm{AUC}_{0-24 \mathrm{~h}}$, area & $\mathrm{AUC}_{0-24 \mathrm{~h}}$, area & $\mathrm{AUC}_{0-24 \mathrm{~h}}$, area & $\mathrm{AUC}_{0-24 \mathrm{~h}}$, area \\
\hline under the plasma & under the plasma & under the plasma & under the plasma & under the plasma \\
\hline concentration & concentration & concentration & concentration & concentration \\
\hline curve from time & curve from time & curve from time & curve from time & curve from time \\
\hline zero to 24 hours & zero to 24 hours & zero to 24 hours & zero to 24 hours & zero to 24 hours \\
\hline post-dose. & post-dose. & post-dose. & post-dose. & post-dose. \\
\hline
\end{tabular}

Table 4 Summary of systemic exposure ${ }^{\mathrm{a}}$ to PC945 in male and female rats following 14 days of inhaled dosing of $2.0,7.1$ and $16.6 \mathrm{mg} / \mathrm{kg} /$ day

\begin{tabular}{lllllll}
\hline $\begin{array}{l}\text { Dose } \\
(\mathbf{m g} / \mathbf{k g})\end{array}$ & Male rats & Male rats & Male rats & Female rats & Female rats & Female rats \\
\hline & $\mathbf{C}_{\text {max }}$ & & & & & \\
$(\mathrm{ng} / \mathrm{mL})$ & $\mathbf{A U C}_{\mathbf{0 - 2 4 h}}$ & & & & \\
$(\mathrm{ng} \cdot \mathrm{h} / \mathrm{mL})$ & $\mathbf{R}_{\mathbf{o}} \mathbf{b}$ & $\mathbf{C}_{\mathbf{m a x}}$ & & & & \\
$(\mathrm{ng} / \mathrm{mL})$ & $\mathbf{A U C}_{\mathbf{0 - 2 4 h}}$ & & & & \\
$(\mathrm{ng} \cdot \mathrm{h} / \mathrm{mL})$ & $\mathbf{R}_{\mathbf{o}}^{\mathbf{b}}$ & & & & & \\
2.0 & 12.3 & 202 & 1.96 & 19.2 & 336 & 1.84 \\
7.1 & 23.7 & 424 & 1.91 & 50.4 & 749 & 1.91 \\
16.6 & 76.9 & 1140 & 2.76 & 92.3 & 1850 & 2.53
\end{tabular}




\begin{tabular}{|c|c|c|c|c|c|c|}
\hline $\begin{array}{l}\text { Dose } \\
(\mathrm{mg} / \mathrm{kg})\end{array}$ & Male rats & Male rats & Male rats & Female rats & Female rats & Female rats \\
\hline Abbreviations: & Abbreviations: & Abbreviations: & Abbreviations: & Abbreviations: & Abbreviations: & Abbreviations: \\
\hline $\mathrm{C}_{\max }$ & $\mathrm{C}_{\max }$ & $\mathrm{C}_{\max }$ & $\mathrm{C}_{\max }$ & $\mathrm{C}_{\max }$ & $\mathrm{C}_{\max }$ & $\mathrm{C}_{\max }$ \\
\hline maximum & maximum & maximum & maximum & maximum & maximum & maximum \\
\hline observed & observed & observed & observed & observed & observed & observed \\
\hline $\begin{array}{l}\text { concentra- } \\
\text { tion: }\end{array}$ & $\begin{array}{l}\text { concentra- } \\
\text { tion: }\end{array}$ & $\begin{array}{l}\text { concentra- } \\
\text { tion: }\end{array}$ & $\begin{array}{l}\text { concentra- } \\
\text { tion: }\end{array}$ & $\begin{array}{l}\text { concentra- } \\
\text { tion: }\end{array}$ & $\begin{array}{l}\text { concentra- } \\
\text { tion: }\end{array}$ & $\begin{array}{l}\text { concentra- } \\
\text { tion: }\end{array}$ \\
\hline $\mathrm{AUC}_{0-24 \mathrm{~h}}$, & $\mathrm{AUC}_{0-24 \mathrm{~h}}$ & $\mathrm{AUC}_{0-24 \mathrm{~h}}$, & $\mathrm{AUC}_{0-24 \mathrm{~h}}$ & $\mathrm{AUC}_{0-24 \mathrm{~h}}$, & $\mathrm{AUC}_{0-24 \mathrm{~h}}$ & $\mathrm{AUC}_{0-24 \mathrm{~h}}$ \\
\hline area under & area under & area under & area under & area under & area & area \\
\hline the plasma & the plasma & the plasma & the plasma & the plasma & the plasma & the plasma \\
\hline concentra- & concentra- & concentra- & concentra- & concentra- & concentra- & oncentra- \\
\hline tion curve & tiol & tio & tio & ve & $\mathrm{ti}$ & ve \\
\hline from time & from & from time & from time & from time & from time & ime \\
\hline zero to 24 & zero to 24 & zero to 24 & zero to 24 & zero to 24 & zero to 24 & ero to 24 \\
\hline hours & hours & hours & hours & hours & hours & hours \\
\hline post-dose; & post-dose; & post-dose; & post-dose; & post-dose; & post-dose; & post-dose; \\
\hline $\mathrm{R}_{\mathrm{o}}$, accumu- & $\mathrm{R}_{\mathrm{o}}$, accumu- & $\mathrm{R}_{\mathrm{o}}$, accumu- & $\mathrm{R}_{\mathrm{o}}$, accumu- & $\mathrm{R}_{\mathrm{o}}$, accumu- & $\mathrm{R}_{\mathrm{o}}$, accumu- & $\mathrm{R}_{\mathrm{o}}$, accumu- \\
\hline & & & & & $\begin{array}{l}\text { lation ratio. } \\
\text { a No }\end{array}$ & $\begin{array}{l}\text { lation ratio. } \\
\text { a No }\end{array}$ \\
\hline tandard & standard & standard & standard & standard & sta & sta \\
\hline eviation on & deviation on & deviation on & deviation on & deviation on & deviation on & deviation on \\
\hline $\begin{array}{l}\text { pharmacoki- } \\
\text { netic }\end{array}$ & $\begin{array}{l}\text { pharmacoki- } \\
\text { netic }\end{array}$ & $\begin{array}{l}\text { pharmacoki- } \\
\text { netic }\end{array}$ & $\begin{array}{l}\text { pharmacoki- } \\
\text { netic }\end{array}$ & $\begin{array}{l}\text { pharmacoki- } \\
\text { netic }\end{array}$ & $\begin{array}{l}\text { pharmacoki- } \\
\text { netic }\end{array}$ & $\begin{array}{l}\text { pharmacoki- } \\
\text { netic }\end{array}$ \\
\hline parameters & parameters & neters & parameters & parameters & parameters & parameters \\
\hline ea & 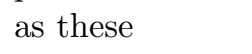 & as & $a_{0}$ & 1 & $2 \mathrm{~s}+\mathrm{s}$ & as $\mathrm{t}$. \\
\hline were derived & were & were & were & were & were & were derived \\
\hline from PC945 & from & C945 & from & from PC945 & from PC945 & from PC945 \\
\hline concentra- & concentra- & concentra- & concentra- & concentra- & concentra- & concentra- \\
\hline $\begin{array}{l}\text { tions in } \\
\text { groups of }\end{array}$ & $\begin{array}{l}\text { tions in } \\
\text { groups of }\end{array}$ & $\begin{array}{l}\text { tions in } \\
\text { groups of }\end{array}$ & $\begin{array}{l}\text { tions in } \\
\text { groups of }\end{array}$ & $\begin{array}{l}\text { tions in } \\
\text { groups of }\end{array}$ & tions in & ions in \\
\hline $\begin{array}{l}\text { groups of } \\
\text { rats per time }\end{array}$ & rats per time & rats per time & rats per time & rats per time & rats per time & rats per time \\
\hline $\begin{array}{l}\text { point. }{ }^{\mathrm{b}} \text { Ac- } \\
\text { cumulation }\end{array}$ & $\begin{array}{l}\text { point. b Ac- } \\
\text { cumulation }\end{array}$ & $\begin{array}{l}\text { point. }{ }^{\mathrm{b}} \text { Ac- } \\
\text { cumulation }\end{array}$ & $\begin{array}{l}\text { point. }{ }^{\mathrm{b}} \text { Ac- } \\
\text { cumulation }\end{array}$ & $\begin{array}{l}\text { point. }{ }^{\mathrm{b}} \text { Ac- } \\
\text { cumulation }\end{array}$ & $\begin{array}{l}\text { point. }{ }^{\mathrm{b}} \text { Ac- } \\
\text { cumulation }\end{array}$ & $\begin{array}{l}\text { point. b Ac- } \\
\text { cumulation }\end{array}$ \\
\hline ratio $\left(R_{o}\right)$ & ratio $\left(\mathrm{R}_{\mathrm{o}}\right)$ & rati & ratio & ratio $\left(\mathrm{R}_{\mathrm{o}}\right)$ & ratio $\left(\mathrm{R}_{\mathrm{o}}\right)$ & ratio $\left(R_{0}\right)$ \\
\hline from & deriv & der & der & om & from & derived from \\
\hline $\mathrm{AUC}_{0-24 \mathrm{~h}}$ & $\mathrm{AUC}_{0-24 \mathrm{~h}}$ & $\mathrm{AUC}_{0-24 \mathrm{~h}}$ & $\mathrm{AUC}_{0-24 \mathrm{~h}}$ & $\mathrm{AUC}_{0-24 \mathrm{~h}}$ & $\mathrm{AUC}_{0-24 \mathrm{~h}}$ & $\mathrm{AUC}_{0-24 \mathrm{~h}}$ \\
\hline (Day14) / & (Day14) / & (Day14) / & (Day14) / & (Day14) / & (Day14) / & (Day14) / \\
\hline $\begin{array}{l}\mathrm{AUC}_{0-24 \mathrm{~h}} \\
(\text { Day 1). }\end{array}$ & $\begin{array}{l}\mathrm{AUC}_{0-24 \mathrm{~h}} \\
(\text { Day 1). }\end{array}$ & $\begin{array}{l}\mathrm{AUC}_{0-24 \mathrm{~h}} \\
(\text { Day 1). }\end{array}$ & $\begin{array}{l}\mathrm{AUC}_{0-24 \mathrm{~h}} \\
(\text { Day 1). }\end{array}$ & $\begin{array}{l}\mathrm{AUC}_{0-24 \mathrm{~h}} \\
(\text { Day 1). }\end{array}$ & $\begin{array}{l}\mathrm{AUC}_{0-24 \mathrm{~h}} \\
(\text { Day 1). }\end{array}$ & $\begin{array}{l}\mathrm{AUC}_{0-24 \mathrm{~h}} \\
(\text { Day 1). }\end{array}$ \\
\hline Day 1 data & Day 1 data & Day 1 data & Day 1 data & Day 1 data & Day 1 data & Day 1 data \\
\hline $\begin{array}{l}\text { are shown in } \\
\text { Table } 2 .\end{array}$ & $\begin{array}{l}\text { are shown in } \\
\text { Table } 2 .\end{array}$ & $\begin{array}{l}\text { are shown in } \\
\text { Table } 2 .\end{array}$ & $\begin{array}{l}\text { are shown in } \\
\text { Table } 2 .\end{array}$ & $\begin{array}{l}\text { are shown in } \\
\text { Table } 2 .\end{array}$ & $\begin{array}{l}\text { are shown in } \\
\text { Table } 2 .\end{array}$ & $\begin{array}{l}\text { are shown in } \\
\text { Table } 2 .\end{array}$ \\
\hline & & & & & & \\
\hline
\end{tabular}

Table 5 Summary of mean ${ }^{\mathrm{a}}$ systemic exposure to PC945 in male and female dogs following 14 days of inhaled dosing of $1.7,5.3$ and $18.1 \mathrm{mg} / \mathrm{kg} /$ day

Dose

$(\mathrm{mg} / \mathrm{kg})$

Male dogs 
Male dogs

Male dogs

Female dogs

Female dogs

Female dogs

$\mathrm{C}_{\max }(\mathrm{ng} / \mathrm{mL})$

$\mathrm{AUC}_{0-24 h}(\mathrm{ng} \cdot \mathrm{h} / \mathrm{mL})$

$\mathbf{R}_{\mathbf{o}}{ }^{\mathbf{b}}$

$\mathrm{C}_{\max }(\mathrm{ng} / \mathrm{mL})$

$\mathrm{AUC}_{0-24 \mathrm{~h}}(\mathrm{ng} \cdot \mathrm{h} / \mathrm{mL})$

$\mathbf{R}{ }^{b}$

1.7

2.8

35.5

2.06

2.3

27.7

2.27

5.3

5.6

70.9

1.84

5.5

73.3

1.88

18.1

13.5

203

2.29

7.8

114

1.26

Abbreviations: $\mathrm{C}_{\max }$, maximum observed concentration; $\mathrm{AUC}_{0-24 \mathrm{~h}}$, area under the plasma concentration curve from time zero to 24 hours post-dose; $R_{0}$, accumulation ratio. ${ }^{a}$ Standard Deviation values were 
omitted for reasons of clarity in presentation of mean data. ${ }^{\mathrm{b}}$ Accumulation ratio (Ro) was derived from $\mathrm{AUC}_{0-24 \mathrm{~h}}$ (Day14) / $\mathrm{AUC}_{0-24 \mathrm{~h}}$ (Day 1). Day 1 data are shown in Table 3.

Abbreviations: $\mathrm{C}_{\max }$, maximum observed concentration; $\mathrm{AUC}_{0-24 \mathrm{~h}}$, area under the plasma concentration curve from time zero to 24 hours post-dose; $\mathrm{R}_{\mathrm{o}}$, accumulation ratio. a Standard Deviation values were omitted for reasons of clarity in presentation of mean data. ${ }^{\mathrm{b}}$ Accumulation ratio (Ro) was derived from $\mathrm{AUC}_{0-24 \mathrm{~h}}$ (Day14) $/ \mathrm{AUC}_{0-24 \mathrm{~h}}$ (Day 1). Day 1 data are shown in Table 3.

Abbreviations: $\mathrm{C}_{\max }$, maximum observed concentration; $\mathrm{AUC}_{0-24 \mathrm{~h}}$, area under the plasma concentration curve from time zero to 24 hours post-dose; $\mathrm{R}_{\mathrm{o}}$, accumulation ratio. ${ }^{\text {a }}$ Standard Deviation values were omitted for reasons of clarity in presentation of mean data. ${ }^{\mathrm{b}}$ Accumulation ratio (Ro) was derived from $\mathrm{AUC}_{0-24 \mathrm{~h}}$ (Day14) $/ \mathrm{AUC}_{0-24 \mathrm{~h}}$ (Day 1). Day 1 data are shown in Table 3.

Abbreviations: $\mathrm{C}_{\max }$, maximum observed concentration; $\mathrm{AUC}_{0-24 \mathrm{~h}}$, area under the plasma concentration curve from time zero to 24 hours post-dose; $\mathrm{R}_{\mathrm{o}}$, accumulation ratio. ${ }^{\text {a }}$ Standard Deviation values were omitted for reasons of clarity in presentation of mean data. ${ }^{b}$ Accumulation ratio (Ro) was derived from $\mathrm{AUC}_{0-24 \mathrm{~h}}$ (Day14) / $\mathrm{AUC}_{0-24 \mathrm{~h}}$ (Day 1). Day 1 data are shown in Table 3.

Abbreviations: $\mathrm{C}_{\max }$, maximum observed concentration; $\mathrm{AUC}_{0-24 \mathrm{~h}}$, area under the plasma concentration curve from time zero to 24 hours post-dose; $R_{0}$, accumulation ratio. a Standard Deviation values were omitted for reasons of clarity in presentation of mean data. ${ }^{b}$ Accumulation ratio (Ro) was derived from $\mathrm{AUC}_{0-24 \mathrm{~h}}$ (Day14) / $\mathrm{AUC}_{0-24 \mathrm{~h}}$ (Day 1). Day 1 data are shown in Table 3.

Abbreviations: $\mathrm{C}_{\max }$, maximum observed concentration; $\mathrm{AUC}_{0-24 \mathrm{~h}}$, area under the plasma concentration curve from time zero to 24 hours post-dose; $\mathrm{R}_{\mathrm{o}}$, accumulation ratio. ${ }^{a}$ Standard Deviation values were omitted for reasons of clarity in presentation of mean data. ${ }^{b}$ Accumulation ratio (Ro) was derived from $\mathrm{AUC}_{0-24 \mathrm{~h}}$ (Day14) / $\mathrm{AUC}_{0-24 \mathrm{~h}}$ (Day 1). Day 1 data are shown in Table 3.

Abbreviations: $\mathrm{C}_{\max }$, maximum observed concentration; $\mathrm{AUC}_{0-24 \mathrm{~h}}$, area under the plasma concentration curve from time zero to 24 hours post-dose; $\mathrm{R}_{\mathrm{o}}$, accumulation ratio. a Standard Deviation values were omitted for reasons of clarity in presentation of mean data. ${ }^{b}$ Accumulation ratio (Ro) was derived from $\mathrm{AUC}_{0-24 \mathrm{~h}}$ (Day14) / $\mathrm{AUC}_{0-24 \mathrm{~h}}$ (Day 1). Day 1 data are shown in Table 3.

Table 6 Summary of mean plasma $\mathrm{C}_{\max }$ and mean lung tissue concentrations of PC945 in male and female rats following 14 days of inhaled dosing of $2.0,7.1$ and $16.6 \mathrm{mg} / \mathrm{kg} /$ day

Achieved Inhaled Dose $(\mathrm{mg} / \mathrm{kg})$

2.0

7.1

16.6

Abbreviation: $\mathrm{C}_{\max }$, maximum observed concentration. ${ }^{\mathrm{a}}$ Ratio was derived from lung tissue PC945 concentration (Day 15

Table 7 Summary of mean and range of cross-species plasma protein binding

Species

Mean percentage

protein bound $^{\mathrm{a}}$

\section{Range of \% bound values across concentration range}

Human

96.6 
94.7-98.6

Dog

91.1

$82.3-97.2$

Rat

97.8

$96.8-98.3$

Mouse

96.2

93.0-98.7

${ }^{\mathrm{a}}$ Mean values for protein binding cover the PC945 range of $0.1 \mu \mathrm{M}$ to $50 \mu \mathrm{M}$. No clear trend of concentration dependent binding was observed.

Table 8 Summary of subjects with treatment-emergent adverse events considered by investigators to be related to study drug (First-in-Human Study)

\begin{tabular}{|c|c|c|c|c|c|c|c|c|}
\hline & $\begin{array}{l}\text { Cohort } \\
\mathbf{1} \\
\text { (Sin- } \\
\text { gle } \\
\text { dose) } \\
\text { n } \\
(\%)\end{array}$ & $\begin{array}{l}\text { Cohort } \\
\mathbf{1} \\
\text { (Sin- } \\
\text { gle } \\
\text { dose) } \\
\mathbf{n} \\
(\%)\end{array}$ & $\begin{array}{l}\text { Cohort } \\
\mathbf{1} \\
\text { (Sin- } \\
\text { gle } \\
\text { dose) } \\
\mathbf{n} \\
(\%)\end{array}$ & $\begin{array}{l}\text { Cohort } \\
\mathbf{1} \\
\text { (Sin- } \\
\text { gle } \\
\text { dose) } \\
\mathbf{n} \\
(\%)\end{array}$ & $\begin{array}{l}\text { Cohort } \\
\mathbf{1} \\
\text { (Sin- } \\
\text { gle } \\
\text { dose) } \\
\mathbf{n} \\
(\%)\end{array}$ & $\begin{array}{l}\text { Cohort } \\
2 \\
\text { (Once } \\
\text { daily } \\
\text { for } 7 \\
\text { days) } \\
\mathbf{n} \\
(\%)\end{array}$ & $\begin{array}{l}\text { Cohort } \\
2 \\
\text { (Once } \\
\text { daily } \\
\text { for } 7 \\
\text { days) } \\
\mathbf{n} \\
(\%)\end{array}$ & $\begin{array}{l}\text { Cohort } \\
3 \\
\text { (Sin- } \\
\text { gle } \\
\text { dose) } \\
\text { n } \\
(\%)\end{array}$ \\
\hline & Placebo $^{a}$ & $\begin{array}{l}\text { PC945 } \\
0.5 \\
\mathrm{mg}\end{array}$ & $\begin{array}{l}\text { PC945 } \\
2 \mathrm{mg}\end{array}$ & $\begin{array}{l}\text { PC945 } \\
5 \mathrm{mg}\end{array}$ & $\begin{array}{l}\text { PC945 } \\
10 \\
\mathrm{mg}\end{array}$ & Placebo & $\begin{array}{l}\text { PC945 } \\
5 \mathrm{mg}\end{array}$ & Placebo \\
\hline $\begin{array}{l}\text { No. } \\
\text { of } \\
\text { sub- } \\
\text { jects } \\
\text { with } \\
\text { treatment- } \\
\text { emergent } \\
\text { ad- } \\
\text { verse } \\
\text { events } \\
\text { at- } \\
\text { tributed } \\
\text { to } \\
\text { study } \\
\text { drug }\end{array}$ & $\begin{array}{l}\mathbf{N}=\mathbf{8} \\
4 \\
(50.00) \\
\\
\mathbf{t -}\end{array}$ & $\begin{array}{l}\mathbf{N}=\mathbf{6} \\
1 \\
(16.67)\end{array}$ & $\begin{array}{l}\mathbf{N}=\mathbf{6} \\
0\end{array}$ & $\begin{array}{l}\mathbf{N}=\mathbf{6} \\
2 \\
(33.33)\end{array}$ & $\begin{array}{l}\mathbf{N}=\mathbf{6} \\
2 \\
(33.33)\end{array}$ & $\begin{array}{l}\mathbf{N}=\mathbf{3} \\
1 \\
(33.33)\end{array}$ & $\begin{array}{l}\mathbf{N}=\mathbf{6} \\
2 \\
(33.33)\end{array}$ & $\begin{array}{l}\mathbf{N}=\mathbf{3} \\
0\end{array}$ \\
\hline Diarrhoea & 0 & 0 & 0 & 0 & $1(16.7)$ & 0 & 0 & 0 \\
\hline $\begin{array}{l}\text { Faeces } \\
\text { soft }\end{array}$ & $\begin{array}{l}1 \\
(12.50)\end{array}$ & 0 & 0 & $\begin{array}{l}1 \\
(16.67)\end{array}$ & 0 & 0 & 0 & 0 \\
\hline
\end{tabular}




\begin{tabular}{|c|c|c|c|c|c|c|c|c|}
\hline & $\begin{array}{l}\text { Cohort } \\
\mathbf{1} \\
\text { (Sin- } \\
\text { gle } \\
\text { dose) } \\
\text { n } \\
(\%)\end{array}$ & $\begin{array}{l}\text { Cohort } \\
\mathbf{1} \\
\text { (Sin- } \\
\text { gle } \\
\text { dose) } \\
\text { n } \\
(\%)\end{array}$ & $\begin{array}{l}\text { Cohort } \\
\mathbf{1} \\
\text { (Sin- } \\
\text { gle } \\
\text { dose) } \\
\text { n } \\
(\%)\end{array}$ & $\begin{array}{l}\text { Cohort } \\
\mathbf{1} \\
\text { (Sin- } \\
\text { gle } \\
\text { dose) } \\
\text { n } \\
(\%)\end{array}$ & $\begin{array}{l}\text { Cohort } \\
\mathbf{1} \\
\text { (Sin- } \\
\text { gle } \\
\text { dose) } \\
\text { n } \\
(\%)\end{array}$ & $\begin{array}{l}\text { Cohort } \\
2 \\
\text { (Once } \\
\text { daily } \\
\text { for } 7 \\
\text { days) } \\
\mathbf{n} \\
(\%)\end{array}$ & $\begin{array}{l}\text { Cohort } \\
2 \\
\text { (Once } \\
\text { daily } \\
\text { for } 7 \\
\text { days) } \\
\mathbf{n} \\
(\%)\end{array}$ & $\begin{array}{l}\text { Cohort } \\
3 \\
\text { (Sin- } \\
\text { gle } \\
\text { dose) } \\
\text { n } \\
(\%)\end{array}$ \\
\hline Nausea & 0 & 0 & 0 & $\begin{array}{l}1 \\
(16.67)\end{array}$ & $\begin{array}{l}1 \\
(16.67)\end{array}$ & 0 & $\begin{array}{l}1 \\
(16.67)\end{array}$ & 0 \\
\hline Fatigue & 0 & $\begin{array}{l}1 \\
(16.67)\end{array}$ & 0 & 0 & 0 & 0 & 0 & 0 \\
\hline $\begin{array}{l}\text { Muscle } \\
\text { spasms }\end{array}$ & 0 & 0 & 0 & $\begin{array}{l}1 \\
(16.67)\end{array}$ & 0 & 0 & 0 & 0 \\
\hline $\begin{array}{l}\text { Musculoske } \\
\text { discomfort }\end{array}$ & $\begin{array}{l}\text { elletal } \\
(12.50)\end{array}$ & 0 & 0 & 0 & 0 & 0 & 0 & 0 \\
\hline Dizziness & 0 & 0 & 0 & $\begin{array}{l}1 \\
(16.67)\end{array}$ & $\begin{array}{l}1 \\
(16.67)\end{array}$ & 0 & 0 & 0 \\
\hline Headache & $\begin{array}{l}1 \\
(12.50)\end{array}$ & 0 & 0 & $\begin{array}{l}1 \\
(16.67)\end{array}$ & $\begin{array}{l}1 \\
(16.67)\end{array}$ & 0 & $\begin{array}{l}1 \\
(16.67)\end{array}$ & 0 \\
\hline Lethargy & 0 & 0 & 0 & $\begin{array}{l}1 \\
(16.67)\end{array}$ & 0 & 0 & 0 & 0 \\
\hline Cough & $\begin{array}{l}1 \\
(12.50)\end{array}$ & 0 & 0 & 0 & 0 & 0 & 0 & 0 \\
\hline $\begin{array}{l}\text { Productive } \\
\text { cough }\end{array}$ & $\begin{array}{l}1 \\
(12.50)\end{array}$ & 0 & 0 & 0 & 0 & 0 & 0 & 0 \\
\hline $\begin{array}{l}\text { Throat } \\
\text { tightness }\end{array}$ & 0 & 0 & 0 & 0 & 0 & $\begin{array}{l}1 \\
(33.33)\end{array}$ & 0 & 0 \\
\hline
\end{tabular}




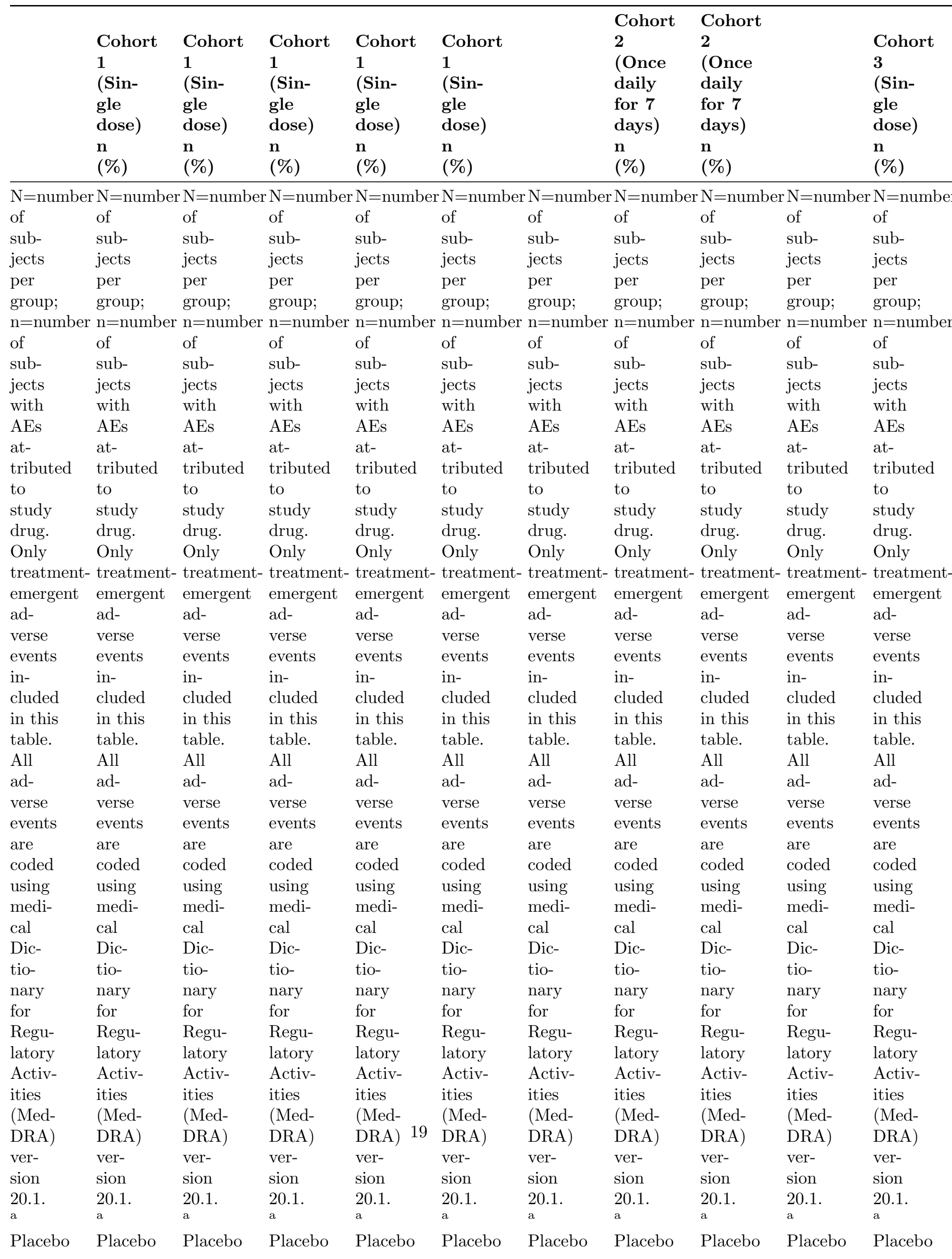




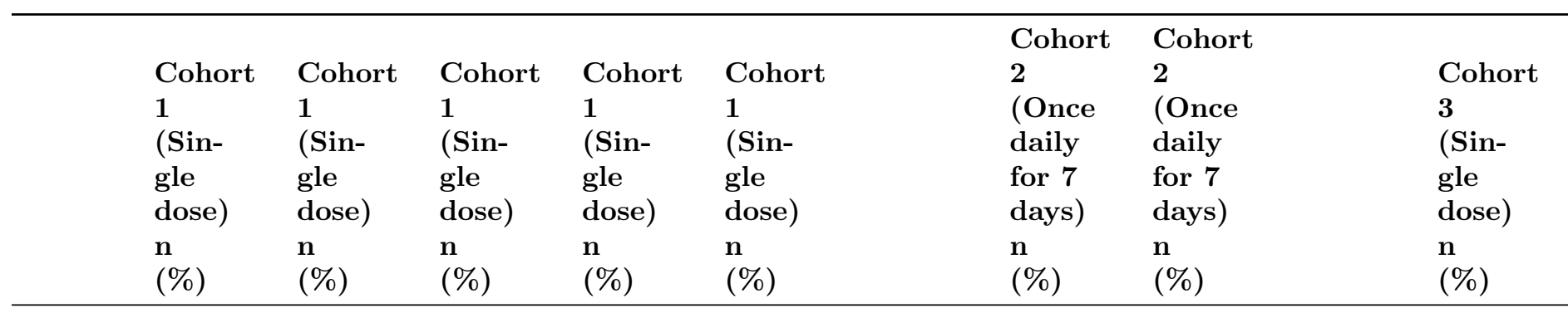

Table 9 Geometric mean (CV\%) pharmacokinetic parameters of PC945 following single doses of PC945 in healthy subjects (Cohort 1)

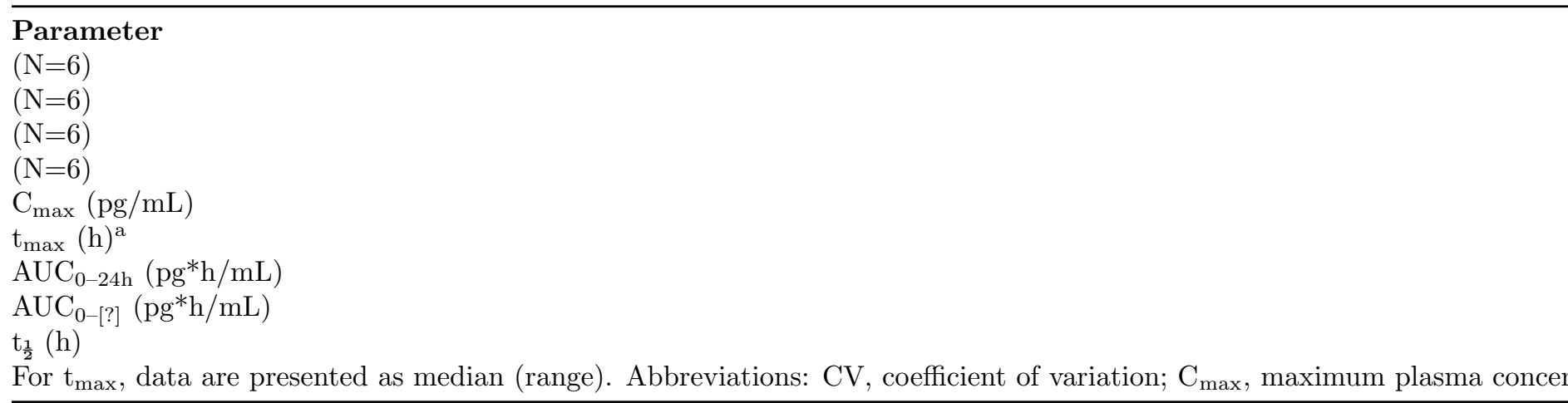

Table 10 Geometric mean (CV\%) pharmacokinetic parameters of PC945 following repeat doses of PC945 5 $\mathrm{mg}$ in healthy subjects (Cohort 2)

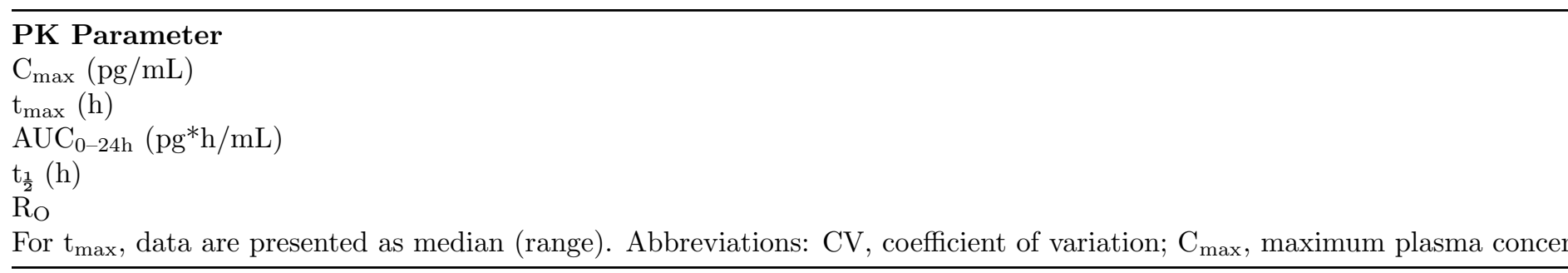

\section{FIGURE LEGENDS}

Figure 1 Subject disposition (CONSORT diagram)

Figure 2 Mean change from baseline in $\mathrm{FEV}_{1}$ for subjects with mild asthma (Cohort 3)

Figure 3 Mean plasma concentrations (linear [A] and log scales [B]) vs. time profiles of PC945 after single-dose administration in healthy subjects (Cohort 1 and Day 1 of Cohort 2) 
Figure 4 Mean plasma concentrations (linear [A] and log scales [B]) vs. time profiles of PC945 following a single inhalation of PC945 $5 \mathrm{mg}$ in healthy subjects (Cohort 1) and subjects with mild asthma (Cohort 3)

Figure 5 Mean plasma concentrations (linear [A] and log scales [B]) vs. time profiles of PC945 following repeat daily administration of PC945 $5 \mathrm{mg}$ in healthy subjects (Cohort 2, Day 1 and Day 7)
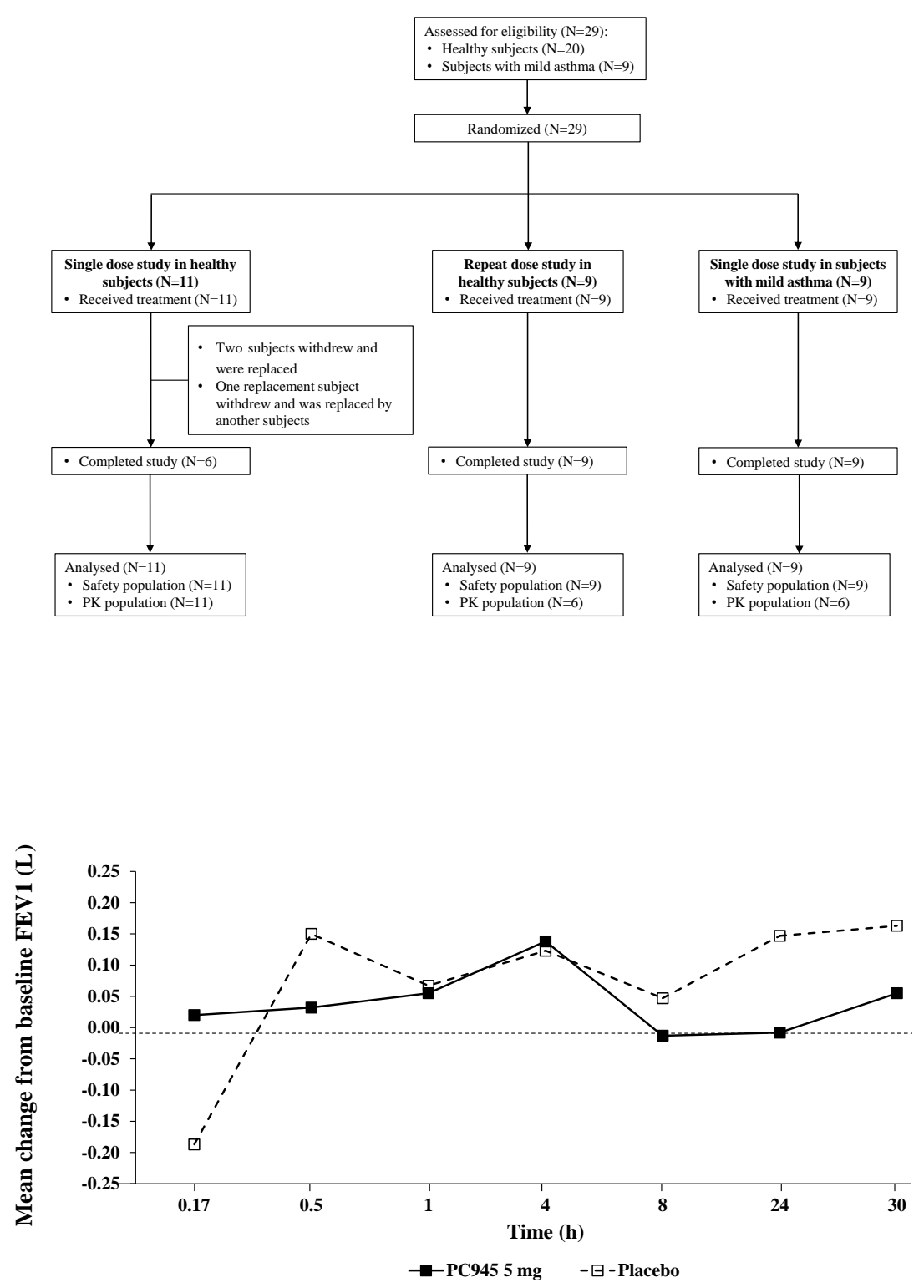
A

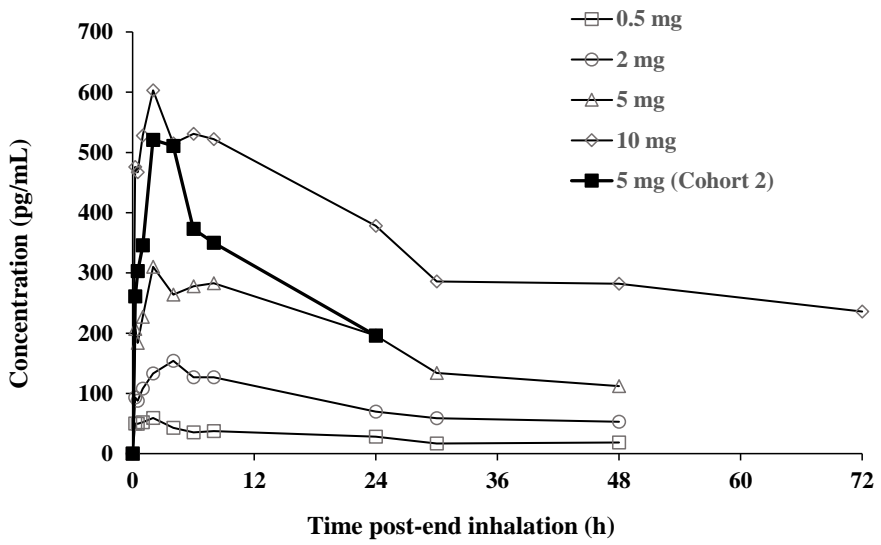

B

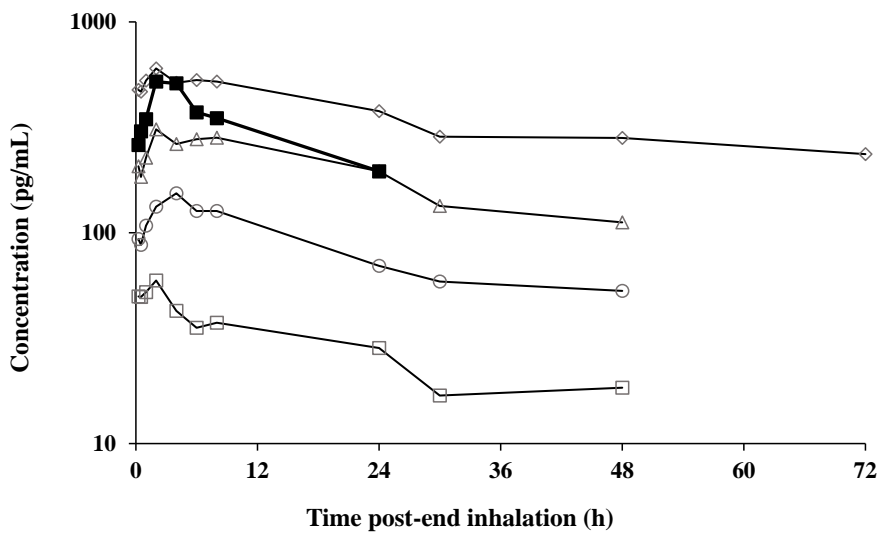


A

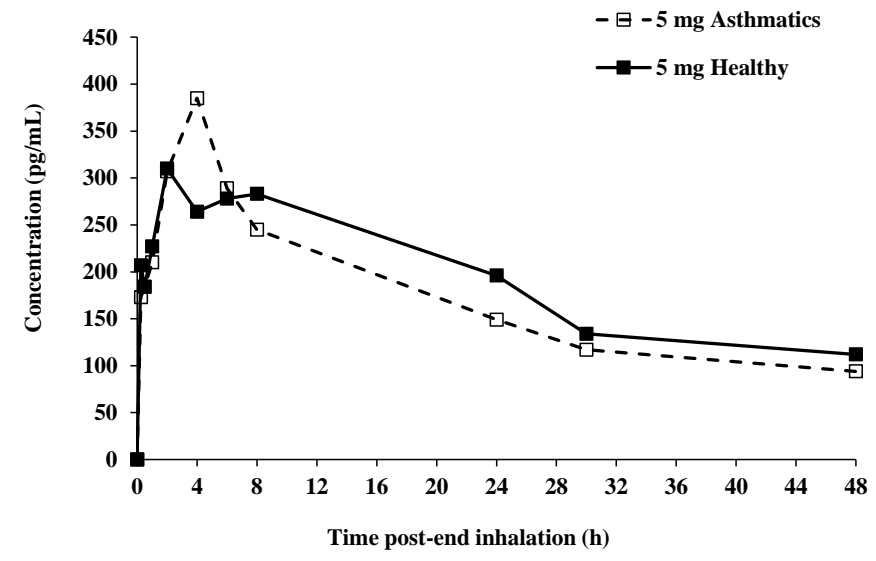

B

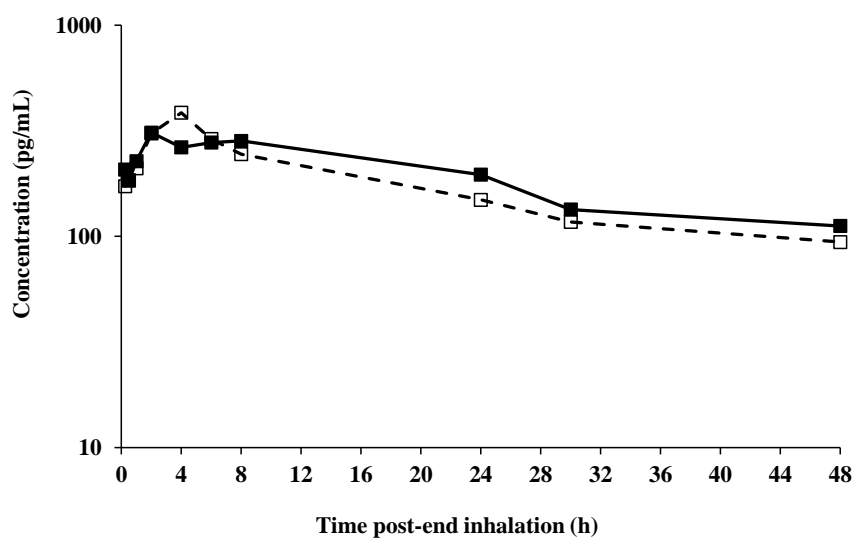


A

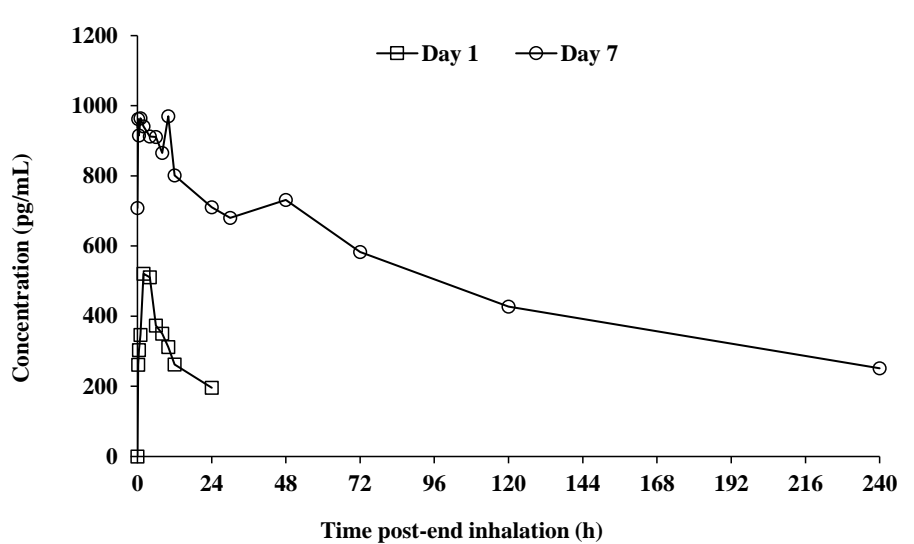

B

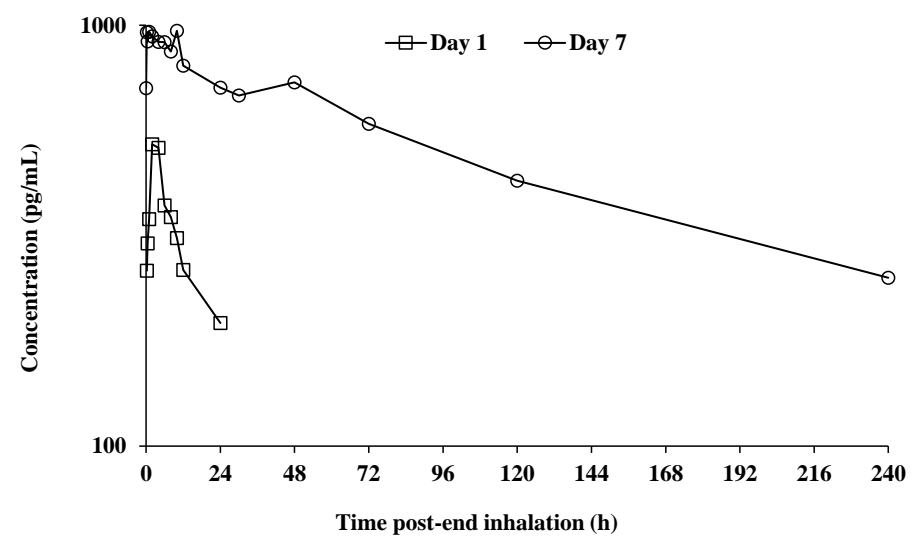

